\title{
Niche differences between two sympatric whiptail lizards (Cnemidophorus abaetensis and C.ocellifer, Teiidae) in the restinga habitat of northeastern Brazil
}

\author{
Dias, EJR.* and Rocha, CFD. \\ Departamento de Ecologia, Instituto de Biologia, Universidade do Estado do Rio de Janeiro, \\ Rua São Francisco Xavier 524, Maracanã, CEP 20550-019, Rio de Janeiro, RJ, Brazil \\ *e-mail: ejrdias@hotmail.com \\ Received December 15, 2004 - Accepted March 14, 2005 - Distributed February 28, 2007
}

(With 2 figures)

\begin{abstract}
Differences among sympatric lizard species usually result from differences in the use of three resources: space, time and food or some combination of these three. However, differences in resource utilization among sympatric species may simply reflect their specific ecological needs rather than competitive pressures. In this study, we analyzed the temporal, spatial and food niche of two congeneric teiids (Cnemidophorus abaetensis and C. ocellifer) living sympatrically in the "restinga" habitat of Abaeté in the Salvador Municipality, Bahia State, Brazil to assess the degree of niche differentiation among them. The whiptail species overlapped considerably in an hourly activity $\left(\mathrm{O}_{\mathrm{jk}}=0.93\right)$, in microhabitat use $\left(\mathrm{O}_{\mathrm{jk}}=0.97\right)$ and in the prey items consumed $\left(\mathrm{O}_{\mathrm{jk}}=0.89\right)$. Differences in amount of vegetation in the microhabitats used by both lizard species may have contributed to differences in the activity period and in the distribution of the main prey eaten by these lizards which may, in turn, facilitate their coexistence in Abaeté. Although sympatric C. ocellifer and C. abaetensis in Abaeté differed only slightly in their use of microhabitats, period of activity and diet, the most important niche dimension segregating the two species seemed to be the food niche.
\end{abstract}

Keywords: whiptail lizards, restinga habitat, diet, sympatry, niche overlap.

\section{Diferenças de nichos entre duas espécies simpátricas de lagartos (Cnemidophorus abaetensis e $C$. ocellifer) em habitat de restinga no nordeste do Brasil}

\begin{abstract}
Resumo
As diferenças entre espécies simpátricas geralmente podem ser atribuídas às variações na utilização de três dimensões primárias de recurso: o período de atividade, o microhabitat e o alimento ou a alguma combinação das três. No entanto, tais diferenças na utilização de recursos entre espécies simpátricas têm sido sugeridas mais como um reflexo de suas necessidades ecológicas específicas do que resultado de pressão competitiva. Neste estudo, avaliou-se o nicho temporal, o espacial e o alimentar de dois teídeos cogenéricos (Cnemidophorus abaetensis e C. ocellifer) vivendo em simpatria na restinga de Abaeté em Salvador, Bahia. As duas espécies de lagartos sobrepõem-se consideravelmente no período de atividade $\left(\mathrm{O}_{\mathrm{jk}}=0,93\right)$, no uso dos microhabitats $\left(\mathrm{O}_{\mathrm{jk}}=0,97\right)$ e nos tipos de presas consumidas $\left(\mathrm{O}_{\mathrm{jk}}=0,89\right)$. As diferenças na quantidade de vegetação nos microhabitats utilizadas pelas duas espécies podem ter contribuído para as diferenças no período de atividade e na distribuição dos principais tipos de presas consumidas por estas duas espécies de lagartos, o que pode ter favorecido a coexistência entre elas na restinga do Abaeté. No entanto, as diferenças na dieta são as mais significativas para a segregação.
\end{abstract}

Palavras-chave: Cnemidophorus, restinga, dieta, simpatria, sobreposição de nicho.

\section{Introduction}

Closely related sympatric species, by using similar resources and thus potentially competing, are usually expected to diverge on one of three niche axes (space, time or food) to coexist (Pianka, 1973, 1986). If species were always packed as tightly together as they could be then, presumably they would differ by the minimum (limiting) amount (Begon et al., 1996). These differences in resource use may not necessarily indicate the occurrence of competition (Schoener, 1968; Pianka, 1973; Vitt, 1995; Vitt and Carvalho, 1995). Differences in resource utilization among sympatric species may simply reflect their specific ecological needs rather than competitive pressures (e.g. Barbault and Maury, 1981, 1985; Ortega et al., 1982; Gonzalez-Romero et al., 1989; Bergallo 
and Rocha, 1994; Vrcibradic and Rocha, 1996). Thus, competition may be less common (Dunham, 1980, 1983; Tinkle, 1982; M'Closkey and Baia, 1987) or less important in community structuring than previously thought (Barbault and Maury, 1981; Gonzalez-Romero et al., 1989).

In restinga (coastal Brazilian sand-dune habitat) of Abaeté (12 $55^{\prime} \mathrm{S}$ and $\left.38^{\circ} 19^{\prime} \mathrm{W}\right)$ in Salvador Municipality, Bahia State, northeastern Brazil two species of whiptail lizards (Teiidae) occur sympatrically: Cnemidophorus ocellifer, which is widespread in cisandean South America, south of Amazonia (Vanzolini et al., 1980;Avila-Pires, 1995; Freire, 1996) and Cnemidophorus abaetensis a recently described species endemic to restinga habitats of the northern Bahia State, Brazil (Dias et al., 2002). No information exists as to what extent these two sympatric species differ in ecological characteristics. Information regarding ecology of C. abaetensis is presently limited to a few "ecological remarks" which accompanied the species' description (Dias et al., 2002). In this study, we analyzed temporal, spatial and food niches of $C$. abaetensis and $C$. ocellifer living sympatrically in the restinga of Abaeté to assess the degree of niche differentiation among them.

\section{Material and Methods}

Restingas are Quaternary coastal sand-dune habitats covered with herbaceous and shrubby xerophilous vegetation belonging to the Atlantic Rainforest biome (Suguio and Tessler, 1984; Eiten, 1992). From March to May, 2000 in the restinga of Dunas do Abaeté, we collected the lizards with rubber bands, euthanized them with ether and fixed them with $10 \%$ formalin. Each lizard captured had its snout-vent length (SVL) measured with a caliper (to the nearest $0.1 \mathrm{~mm}$ ). The lizard's SVL was compared between species using a t-test (Zar 1999).

To evaluate the temporal niche of the two lizard species, we made 50 transects (choice at random) each with $250 \mathrm{~m}$ length for $20 \mathrm{~min}$ at hourly intervals between 8 and 18 hours over five days. During each transect, we recorded the number of active individuals of each species. Interspecific differences in times of activity were tested using Kolmogorov-Smirnov Test (Siegel, 1956).

The spatial niches of the species were analysed by assessing habitat use by each lizard species according to four microhabitat categories, which correspond to the main microhabitats available in the area: 1) on bare sand outside bushes (BSA); 2) under herbaceous vegetation (HERB); 3) on sand under shrubs (SUS); and 4) on leaf litter under shrub (LLS). Interspecific differences in microhabitat use were tested using the KolmogorovSmirnov Test (Siegel, 1956). We also estimated the height of the vegetation (in $\mathrm{cm}$ ) in the microhabitat above the lizard and the distance (in $\mathrm{cm}$ ) from the edge to the bush (both at the moment the lizard was first sighted) and tested for differences between both species using a t-test (Zar, 1999).
For food niche analyses, we removed lizard stomachs and sorted prey items by Order. The length and width of each prey were measured with a caliper (to the nearest $0.1 \mathrm{~mm})$ and individual prey volume $\left(\mathrm{mm}^{3}\right)$ was estimated using the formula for a prolate spheroid (Vitt, 1991):

$$
\mathrm{V}=\frac{4}{3 \pi(C)(L)^{2}}
$$

Where $\mathrm{C}$ is half of the length and $\mathrm{L}$ is half of the width. The mean prey volume (based on the five largest items) and number of prey per lizard were compared between the two lizard species using a t-test (Zar, 1999).

To estimate the time, food and spatial niche breadth for each species, we used Simpson's (1949) index of diversity.

$$
\mathrm{B}_{\mathrm{ij}}=\frac{1}{\sum_{\mathrm{i}=1}^{\mathrm{n}} p i^{2}}
$$

where $p i$ is the proportion of lizards associated to each type of resource.

We used the coefficient of symmetry of overlapping (Pianka, 1986) to estimate overlap in the above niches between species.

$$
\mathrm{O}_{\mathrm{jk}}=\frac{\sum_{i=1}^{n} p i j \times p i k}{\sqrt{\sum_{i=1}^{n} p i j^{2} \sum_{i=1}^{n} p i k^{2}}}
$$

In this Equation, the symbols are the same as for niche breadth and $j$ and $k$ represent lizard species. The values of overlap can vary from 0 (no overlap) to 1 (complete overlap).

\section{Results}

Cnemidophorus abaetensis (mean SVL $=54.8 \pm$ $10.6 \mathrm{~mm} ; \mathrm{N}=33$ ) was larger on average than $C$. ocellifer $($ mean SVL $=50.6 \pm 5.1 \mathrm{~mm} ; \mathrm{N}=40)(t=-2.08$; $\mathrm{df}=44.1 ; \mathrm{p}<0.05)$.

Both species were active almost all day, but most activity occurred during mid to late morning. The first active $C$. ocellifer was sighted at 8 hours and, following that, the number of active lizards increased until reaching a maximum between 10 and 11 hours. After 15 hours the number of active $C$. ocellifer gradually decreased, ceasing before 17 hours. For C. abaetensis, the first active individuals were recorded between 8 and 9 hours, with a peak of activity between 10 and 11 hours. After 13 hours individuals of $C$. abaetensis were rarely seen. We found significant differences in hourly activity between both species (Kolmogorov-Smirnov Test, $\mathrm{D}_{\max }=0.18$; $\mathrm{p}<0.001)$. The temporal niche breadth of $C$. ocellifer $\left(B_{i j}=6.70\right)$ was greater than that of $C$. abaetensis $\left(B_{i j}=4.62\right)$ and temporal niche overlap $\left(O_{j k}\right)$ between them was 0.93 (as shown in Table 1).

The microhabitat used most by both species was the leaf litter under shrubs (C. ocellifer, $77.5 \% ; \mathrm{N}=40$ 

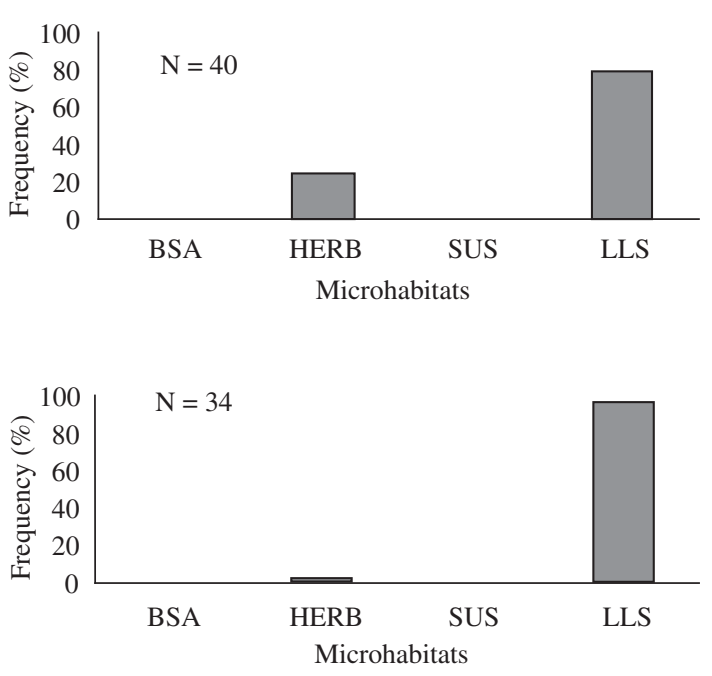

Figure 1. Frequency of microhabitats used by Cnemidophorus ocellifer (above) and by Cnemidophorus abaetensis at "restinga" of Abaeté, Salvador, Bahia, Brazil. $\mathrm{BSA}=$ On bare sand outside of bush; HERB = Among or under herbaceous vegetation; SUS $=$ On sand under shrub and LLS $=$ On leaf litter under shrub.

Table 1. Temporal, food and spatial niche breadth $\left(\mathrm{B}_{\mathrm{ij}}\right)$ and respective overlap $\left(\mathrm{O}_{\mathrm{jk}}\right)$ for Cnemidophorus abaetensis and Cnemidophorus ocellifer at "restinga" of Abaeté, Salvador, Bahia, Brazil.

\begin{tabular}{lcccc}
\hline & \multicolumn{2}{c}{$\begin{array}{c}\text { Cnemidophorus } \\
\text { abaetensis }\end{array}$} & & \multicolumn{2}{c}{$\begin{array}{c}\text { Cnemidophorus } \\
\text { ocellifer }\end{array}$} \\
\cline { 2 - 2 } \cline { 5 - 6 } Niche dimension & $\mathbf{B}_{\mathrm{ij}}$ & & $\mathbf{B}_{\mathrm{ij}}$ & $\mathbf{O}_{\mathbf{j} \mathrm{k}}$ \\
\hline Time & 4.62 & & 6.70 & 0.93 \\
Space & 1.06 & & 1.54 & 0.97 \\
Food & 1.69 & & 1.18 & 0.89 \\
\hline
\end{tabular}

and C. abaetensis, 97.1\%; $\mathrm{N}=34$ ) (Figure 1). Among the available microhabitats in the restinga, neither species was captured in sites without litter or on bare sand outside bushes. There were no significant differences between species in the microhabitat used (KolmogorovSmirnov Test, $\left.\mathrm{D}_{\max }=0.196 ; \mathrm{p}>0.05\right)$. The spatial niche breadth for $C$. ocellifer $\left(B_{i j}=1.54\right)$ was similar to that of C. abaetensis $\left(B_{i j}=1.06\right)$ and the spatial niche overlap among the two species was 0.97 (as show in Table 1). Furthermore, Cnemidophorus ocellifer was primarily associated to microhabitats with a vegetation height ranging from 50 to $100 \mathrm{~cm}(42.5 \%)$ whereas C. abaetensis was found more frequently under vegetation higher than $150 \mathrm{~cm}(58.8 \%)$. The two species differed significantly with respect to the vegetation height in the microhabitats they used $(t=-3.41 ; \mathrm{df}=70.9 ; \mathrm{p}<0.005)$. However, they did not differ in the distance from the edge of bushes (75\% of lizards were at c.a. $100 \mathrm{~cm}$ from the edge of bushes) $(t=-0.70 ; \mathrm{df}=70.9 ; \mathrm{p}=0.48)$.
The diet of C. abaetensis and C. ocellifer consisted of small arthropods with the presence of many parts of plants (as shown in Table 2). The most frequent items in the diet of $C$. abaetensis were Lepidopteran larvae (50\% of stomachs), Aranae (32.4\%) and fruits (23.5\%) (as shown in Table 2). Volumetrically, Lepidopteran larvae (26.7\% of total volume) predominated, followed by Orthoptera (17.8\%) and Blattaria (13.9\%). Numerically, Isoptera (21.9\% of total prey ingested), Lepidopteran larvae $(17.1 \%)$ and Coleoptera $(12.3 \%)$ dominated the diet (as shown in Table 2). For C. ocellifer, Isoptera (47.5\% of the stomachs), Aranae (40\%) and Lepidopteran larvae were the items most frequently consumed. Volumetically, Isoptera (20.6\%), fruits (18.7\%) and Lepidopteran larvae $(15.6 \%)$ dominated the diet. Numerically, Isoptera was the most representative prey type $(59.5 \%$ of total prey ingested) (as shown in Table 2). Cnemidophorus abaetensis and $C$. ocellifer had significant differences in terms of the mean number of prey consumed $(t=3.47$; $\mathrm{df}=46.5 ; \mathrm{p}<0.005$ ), mainly for Isoptera (termites - see Figure 2) $(\mathrm{t}=2.83 ; \mathrm{df}=22.7 ; \mathrm{p}<0.05)$. However, they did not differ in the mean volume of prey ingested $(\mathrm{t}=-0.06 ; \mathrm{df}=58.7 ; \mathrm{p}>0.05)$. The food niche breadth of C. abaetensis $\left(B_{i j}=1.69\right)$ was slightly greater than that of $C$. ocellifer $\left(B_{i j}=1.18\right)$ and the food niche overlap bewteen the two species was 0.89 (as shown in Table 1).

\section{Discussion}

The two Cnemidophorus species overlaped greatly in temporal niche, but differed somewhat in their daily activity patterns. The time niche breadth of C. ocellifer was wider than that of C. abaetensis, probably because of the difference in the extent of activity period. Cnemidophorus ocellifer, in general, remained active for approximately two hours longer than C. abaetensis. The differences in activity period for these two whiptail lizards may be related to the differences in vegetation coverage in the microhabitats used (e.g. Grover, 1996). Cnemidophorus abaetensis used microhabitats with a greater vegetation height above ground (and thus, supposedly shadier) than $C$. ocellifer. This difference may reflect differences in exposure to sunlight (especially in the hottest hours of the day), which would facilitate $C$. abaetensis easier access to heat sources that might reduce its activity period. Many species of sympatric lizards share spatial resources, so that larger species use microhabitats with more vegetation than smaller species (Pianka, 1986). Cnemidophorus abaetensis and C. ocellifer differed in body size and in the vegetation height of the microhabitats used (with the larger C. abaetensis using microhabitats with higher plant cover). Because they are congeneric, these two species have similar ecologies. Therefore, differences in microhabitat use and in lizard body size may facilitate the coexistence of the two whiptail lizards at Abaeté.

Cnemidophorus abaetensis and C. ocellifer also overlapped considerably in their food niche, but this was the niche dimension in which the two species differed 
Table 2. Number $(\mathrm{N})$, volume $(\mathrm{V})$ in $\mathrm{mm}^{3}$, proportions $(\%)$ and frequency $(\mathrm{F})$ of each prey taxon in the diet of Cnemidophorus abaetensis $(\mathrm{N}=34)$ and of Cnemidophorus ocellifer $(\mathrm{N}=40)$ at " restinga"of Abaeté, Salvador, Bahia, Brazil.

\begin{tabular}{|c|c|c|c|c|c|c|c|c|c|c|}
\hline \multirow[t]{2}{*}{ Prey type } & \multicolumn{5}{|c|}{ C. abaetensis } & \multicolumn{5}{|c|}{ C. ocellifer } \\
\hline & $\mathbf{N}$ & $\%$ & $\mathbf{V}$ & $\%$ & $\mathbf{F}$ & $\mathbf{N}$ & $\%$ & $\mathbf{V}$ & $\%$ & $\mathbf{F}$ \\
\hline Isoptera & 32 & 0.22 & 289.10 & 0.05 & 0.21 & 314 & 0.59 & 1504.02 & 0.21 & 0.47 \\
\hline Orthoptera & 11 & 0.07 & 952.25 & 0.18 & 0.21 & 39 & 0.07 & 791.68 & 0.11 & 0.32 \\
\hline Coleoptera & 4 & 0.03 & 144.72 & 0.03 & 0.09 & 26 & 0.05 & 557.84 & 0.08 & 0.15 \\
\hline Homoptera & 3 & 0.02 & 12.38 & 0.002 & 0.06 & 14 & 0.03 & 327.42 & 0.04 & 0.1 \\
\hline Hymenoptera & 3 & 0.02 & 10.93 & 0.002 & 0.09 & 6 & 0.01 & 281.27 & 0.04 & 0.1 \\
\hline $\begin{array}{l}\text { Hymenoptera } \\
\text { (alated) }\end{array}$ & - & - & - & - & - & 2 & 0.004 & 9.06 & 0.001 & 0.05 \\
\hline Blattaria & 7 & 0.05 & 747.44 & 0.14 & 0.12 & - & - & - & - & - \\
\hline Diptera & 1 & 0.01 & 0.18 & - & 0.03 & 2 & 0.004 & 13.21 & 0.002 & 0.05 \\
\hline Lepidoptera & - & - & - & - & - & 1 & 0.002 & 3.63 & - & 0.03 \\
\hline \multicolumn{11}{|l|}{ Larvae } \\
\hline Coleoptera & 18 & 0.12 & 262.91 & 0.05 & 0.21 & 28 & 0.05 & 605.96 & 0.08 & 0.33 \\
\hline Lepidoptera & 25 & 0.17 & 1431.42 & 0.27 & 0.50 & 36 & 0.07 & 1140.06 & 0.16 & 0.38 \\
\hline \multicolumn{11}{|l|}{ Nimph } \\
\hline Homoptera & - & - & - & - & - & 3 & 0.01 & 87.90 & 0.01 & 0.05 \\
\hline Hemiptera & - & - & - & - & - & 1 & 0.002 & 36.49 & 0.005 & 0.02 \\
\hline Ortoptera & - & - & - & - & - & 6 & 0.01 & 48.45 & 0.01 & 0.05 \\
\hline Pupae & 3 & 0.02 & 224.82 & 0.04 & 0.09 & 2 & 0.004 & 33.77 & 0.005 & 0.05 \\
\hline Araneida & 15 & 0.10 & 522.40 & 0.10 & 0.32 & 35 & 0.07 & 467.94 & 0.06 & 0.4 \\
\hline Pseudoescorpiones & - & - & - & - & - & 1 & 0.002 & 4.09 & 0.001 & 0.03 \\
\hline Isopoda & 3 & 0.02 & 110.52 & 0.02 & 0.09 & - & - & - & - & - \\
\hline Gastropoda & 2 & 0.01 & 12.71 & 0.002 & 0.06 & - & - & - & - & - \\
\hline \multicolumn{11}{|l|}{ Plant parts } \\
\hline Fruits & 18 & 0.12 & 613.48 & 0.11 & 0.23 & 9 & 0.02 & 1362.60 & 0.19 & 0.23 \\
\hline Totals & 146 & 1.00 & 5362.20 & 1.00 & & 528 & 1.00 & 7304.14 & 1.00 & \\
\hline
\end{tabular}

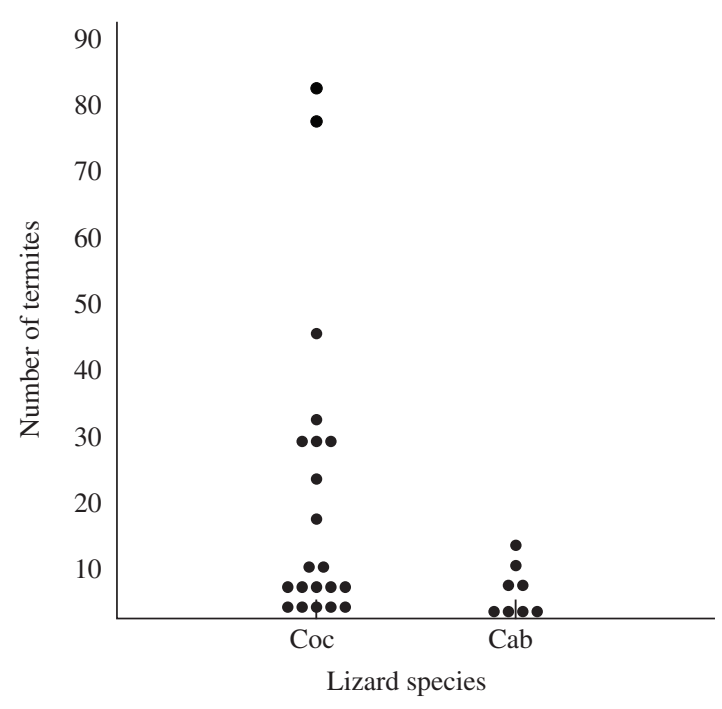

Figure 2. Number of termites in the diet of Cnemidophorus ocellifer (Coc) $(\mathrm{N}=21)$ and of Cnemidophorus abaetensis (Cab) $(\mathrm{N}=8)$ at "restinga" of Abaeté, Salvador, Bahia, Brazil. the most. In part, the differences may be due to the differences in the proportion of termites they consume. For C. abaetensis, larvae were the most frequently consumed items. For $C$. ocellifer, larvae were also an important food resource, but termites were the most important prey. Probably, termites and larvae do not have a homogeneous distribution among the microhabitats available and due to the differences in proportion of vegetation in microhabitats used by these two whiptail lizards, the proportion of termites and larvae may differ. An increased frequency of larvae may be attributed directly to an increase in vegetation height and may result from the more mesic conditions (e.g. Milstead, 1965). Such conditions could also favor the occurrence of termites, but since termites reside in "adobe castles" or underground, the lizards must dig to obtain them. Larvae, when available, would be preferentially taken by lizards compared to termites, because larvae are active in unprotected areas (Milstead, 1965). The food niche breadth of C. ocellifer was $30 \%$ smaller than that of $C$. abaetensis, probbaly due to differences in the proportion of termites consumed among lizard species. Segregation in food niche resulting from differences in microhabitat use is common in teiid liz- 
ards (e.g. Araújo, 1991; Zaluar and Rocha, 2000). For example, in a restinga habitat in Rio de Janeiro State, the cogeneric $C$. littoralis has a more specialized food niche, feeding predomimantly on termites (TeixeiraFilho et al., 2003), compared to the other sympatric teiid, Ameiva ameiva, which feeds mainly on blattarians, larvae and spiders (Zaluar and Rocha, 2000). These differences in the food niche result from differences in body size and foraging sites (A. ameiva is larger feeds mainly in the center of bushes whereas $C$. littoralis forages at bush edges) (Zaluar and Rocha, 2000; Teixeira-Filho et al., 2003). Probably, a similar process ocurr among sympatric Cnemidophorus species in Abaeté, but in this case, the vegetation height seems to be an important factor.

We conclude that the two sympatric teeids C. ocellifer and C. abaetensis in Abaeté differ only slightly in their use of microhabitats, period of activity and diet. The most important niche dimension segregating the two species seemed to be the food niche and this may result from the smaller food niche breadth of C. ocellifer compared to that of C. abaetensis, which in turn, are probably due to differences in the proportion of termites consumed among lizard species. The differences in the height of vegetation in the microhabitats used by both species may somewhat affect the extent of the activity period and the distribution of the main prey eaten by these lizards.

Acknowledgments - This study is part of the results of the "Programa de Ecologia, Conservação e Manejo de Ecossistemas do Sudeste Brasileiro" and of the Southeastern Brazilian Vertebrate Ecology Project (Vertebrate Ecology Laboratory), both of the Setor de Ecologia, Instituto de Biologia, Universidade do Estado do Rio de Janeiro. We would like to thank M. Van Sluys, VA. Menezes and D. Vrcibradic for revising the manuscript and offering helpful suggestions. Rejane ML. Silva from the Universidade Federal da Bahia provided some logistic support. We would also like to thank Marta MF. Vargens for field assistantship. The Instituto Brasileiro do Meio Ambiente e Recursos natturais Renováveis - IBAMA conceded permits for the collection of lizards for our study. The Fundação de Amparo à Pesquisa do Estado do Rio de Janeiro (FAPERJ) provided a Graduate fellowship for the senior author (Process n ${ }^{\circ}$. E-26/150.898/2001) and the Conselho Nacional do Desevolvimento Científico e Tecnológico (CNPq) provided a research grant to the second author (Processes n ${ }^{\circ} 307653 / 2003$ and 477715/2006-0, edital universal).

\section{References}

ARAÚJO, AFB., 1991. Structure of a White Sand-Dune Lizard Community of a Coastal Brazil. Rev. Bras. Biol., vol. 51, no. 4, p. $857-865$.

AVILA-PIRES, TCS., 1995. Lizards of Brazilian Amazonia (Reptilia: Squamata). Zool. Verth., Holanda, 700p. il.

BARBAULT, R. and MAURY, ME., 1981. Ecological organization of Chihuahuan desert lizard community. Oecology., vol. 51 , p. 335-342.

BARBAULT, R., ORTEGA, A. and MAURY, ME., 1985. Food partitioning and community organization in a mountain lizard guild of northern Mexico. Oecologia., vol. 65, p. 550-554.
BEGON, M., HARPER, JL. and TOWSEND, CR., 1996. Ecology, Third Edition, 1070p., Blackwell Science, London.

BERGAlLO, HG. and ROCHA, CFD., 1994. Spatial and Trophic Niche Differentiation in Two Sympatric Lizards (Tropidurus torquatus and Cnemidophorus ocellifer) with Different Foranging Mode. Australian Journal of Ecology., vol. 19 , p. $72-75$.

DIAS, EJR., ROCHA, CFD. and VRCIRBRADIC, D., 2002. A New Cnemidophorus (Squamata; Teiidae) from Bahia State, Northeastern Brazil. Copeia., vol. 4, p. 1070-1077.

DUNHAM, AE., 1980. An experimental study of interspecific competition between the iguanid lizards Sceloporus merriami and Urosaurus ornatus. Ecol. Monogr., vol. 50, p. 309-330.

DUNHAM, AE., 1983. Realized niche overlap, resource abundance and intensity of interspecific competition. In: R. B. Huey, E. R. Pianka and T. W. Schoener (ed), Lizards Ecology: Studies of Model Organism Harvard Univ. Press, Cambridge, Massachusetts.

EITEN, G., 1992. Natural Brazilian vegetation types and their causes. Anais Academ. Bras. Ciênc., vol. 64, suppl. 1, p. 35-65.

FREIRE, EMX., 1996. Estudo Ecológico e Zoogeográfico Sobre a Fauna de Lagartos (Sauria) das Dunas de Natal, Rio Grande do Norte e da Restinga de Ponta de Campina, Cabedelo, Paraíba, Brasil. Rev. Bras. Zool., vol. 13, no. 4, p. 903-921.

FUTUYMA, DJ., 1992. Biologia Evolutiva. Sociedade Brasileira de Genética, Ribeirão Preto (Tradução), 452p.

GOZÁLEZ-ROMERO, A. ORTEGA, A., and BARBAULT, R., 1989. Habitat partitioning and spatial organization in a lizard community of the Sonora Desert, Mexico. Amphibia-Reptilia, vol. 10, p. 1-11.

GROVER, MC., 1996. Microhabitat use and Thermal Ecology of Two Narrowly Sympatric Sceloporus (Phrynosomatidae) Lizards. J. Herpet., vol. 2, no. 2, p. 152-160.

M'ClOSKEY, RT. and BAIA, KA., 1987. Assessment of competitive interations between two iguanid lizard species. Oikos., vol. 48, no. 4, p. 206-210.

MILSTEAD, WW., 1965. Changes in Competing Population of Whiptail Lizards (Cnemidophorus) in Southwestern Texas. The American Midland Naturalist., vol. 73, no. 1, p. 75-80.

ORTEGA, A., GONZALEZ-ROMERO, A. and BARBAULT, R., 1982. Spatial organization and habitat partitioning in a mountain lizard community of northern Mexico. Acta Oecol., vol. 3, p. 323-330.

PIANKA, ER., 1973. The structure of lizards communities. Ann. Rev. Ecol. Syst., vol. 4, no. 53-74.

PIANKA. ER., 1986. Ecology and Natural History of Desert Liazrds. Princeton University Press, Princenton, 208p.

SCHOENER, TW., 1968. The Anolis lizards of Bimini: resources partitioning in a complex fauna. Ecology., vol. 49, p. 704-726.

SCHOENER, TW., 1977. Competition and niche. In: C. Gans and D. W. Tinkle (ed) Biology of Reptilia. Academic Press, New York.

SIEGEL, S., 1956. Nonparametric Statistic for Behavioral Sciences. McGraw-Hill, New York, 312p. 
SIMPSON, EH., 1949. Measurement of diversity. Nature, vol. 163, p. 688.

SUGUIO, K. and TESSLER, MG., 1984. Planícies de cordões litorâneos Quaternários do Brasil: origem e nomenclatura. In LACERDA, L. D., ARAÚJO, D. S. D., CERQUEIRA, R. and TURCQ, B. (eds.) Restingas: Origem, Estrutura, Processos. Centro Editorial da Universidade Federal Fluminense, Niterói.

TEIXEIRA-FILHO, PFP., ROCHA CFD. and RIBAS SC., 2003. Relative feeding specialization may depress ontogenetic, seasonal and sexual variations in diet: the case of the active forager lizard Cnemidophorus littoralis (Teiidae) in a restinga habitat. Braz. J. Biol., vol. 63, no. 2, p. 1-6.

TIKLE, DW., 1982. Result of experimental density manipulation in na Arizona lizard community. Ecology., vol. 63, p. 57-65.

VANZOLINI, PE., RAMOS-COSTA, AM. and VITT, LJ., 1980. Répteis das caatingas. Rio de Janeiro: Academia Brasileira de Ciência, 161p.

VITT, LJ., 1991. An Introduction to the Ecology of Cerrado Lizards., J. Herpetol., vol. 25, no. 1, p. 79-90.
VITT, LJ., 1995. The ecology of tropical lizards in the Caatinga of Northeast Brazil. Occasional Papers of the Oklahoma Museum of Natural History, vol. 1, p. 1-29.

VITT , LJ. and CARVALHO, CM., 1995, Niche Partitioning in a Tropical Wet Season: Lizard in the Lavrado Area of Northern Brazil. Copeia., vol. 2, p. 305-329.

VRCIBRADIC, D. and ROCHA, CFD., 1996. Ecological Differences in Tropical Sympatric Skinks (Mabuya macrorhyncha and Mabuya agilis) in the Southeaestern Brazil. J. Herpetol., vol. 1, no. 1, p. 60-67.

ZALUAR, HLT. and ROCHA, CFD., 2000. Ecology of the Wide-Foraging Lizard Ameiva ameiva (Teiidae) in a Sand Dune Habitat of Southeast Brazil: Ontogenetic, Sexual and Seasonal Trends in Food Habitats, Activity, Thermal Biology and Microhabitat Use. Ciência e Cultura, vol. 2, no. 2, p. 101-107.

ZAR, JH., 1999. Biostatistical Analysis. Prentice-Hall, Englewood Cliffs, New Jersey, 718p. 